ORIGINALN I ČLANAK

\title{
Comparasion between European elite senior and junior female table tennis players: Rally length and serve-receive game
}

Uporedna analiza vrhunskih evropskih seniorki i juniorki u stonom tenisu: dužina poena i igra posle serve i prijema serve

Jason Davide Luini, Faculty of Kinesiology, Split

Michael Fuchs, TUM Department of Sport and Health Sciences, Munich

Zoran Djokic, Faculty of Sport and Tourism, Novi Sad

Ivan Malagoli Lanzoni, Dept. of Biomedical and Neuromotor Sciences, Bologna Goran Munivrana, Faculty of Kinesiology, Split

ABSTRACT

Keywords: Notational analysis, Tactical analysis, Young development, Career transition

SAŽETAK

Ključne reči: notaciona analiza,
The aim of the study was to compare elite junior and senior women table tennis players, using three parameters of the table tennis: rally length, serve and receive analysis. Twentyfive junior and twenty-five elite senior matches were analysed (total: 263 sets and 4958 points) between players ranked in Top 25 in ETTU rankings in the last two years. All the athletes used an offensive style of play. The results of non-parametric Mann-Whitney U Test, showed a significantly higher rally length in senior compared to junior category (4.46 vs. 3.93). Moreover, the results of Pearson's Chi-square tests show an association between the age categories and selected parameters (laterality, technique and placement) for both serve and receive. Different behavior between the two categories was noted. The senior players used more the flip technique $(22.2 \%$ vs $14.7 \%)$ and short push to return the services of the opponents (32.5\% vs $26.0 \%$ ). These results provide useful information to analyze junior players' behavior compared to the senior players in order to plan specific training sessions. It can be also useful to identify some parameters as predictors of the future success for junior players.

Cilj istraživanja bila je uporedna analiza elitnih juniorskih i seniorskih igračica, posmatranjem tri parametra igre u stonom tenisu: dužina poena, analiza servisa i prijema. Analizirano je dvadeset pet juniorskih i dvadeset pet seniorskih mečeva (ukupno: 263 seta i 4958 poena) između igrača koji su rangirani u Top 25 na ETTU rang listi u poslednje dve godine. Sve analizirane stonoteniserke su igrale ofanzivnim stilom. Rezultati neparametrijskog Mann-Vhitnei U testa 
Luini, J. D., Fuchs, M., Djokic, Z., Malagoli Lanzoni, I. Munivrana, G. -

Comparasion between European elite senior and junior female table tennis players

2021. Fakultet za sport i turizam, Novi Sad, Tims.Acta 15, 5-12

taktička analiza, pokazali su značajno veću dužinu poena kod seniorki u odnosu na juniorke (4,46 prema

razvoj mladih $\quad 3,93)$. Štaviše, rezultati Pearsonovog Hi-kvadrat testa pokazuju povezanost između starosnih

sportista, kategorija i izabranih parametara (lateralnost, tehnika i plasiranje udaraca) i kod serve i kod

tranzicija u prijema serve. Posebno su primećene razlike u primeni flip udaraca u korist seniorki $(22,2 \%$

uzrasnim naspram 14,7 \%) i kratko plasirane loptice prilikom prijema protivničke serve (32,5\% prema

kategorijama 26,0 \%). Ovi rezultati pružaju korisne informacije za analizu ponašanja mlađih igrača u odnosu na starije igrače u cilju planiranja treninga. Takođe, moguće je identifikovanje nekih parametara igre kao prediktora budućeg uspeha juniorskih igračica.

TIMS Acta (2021) 15, 5-12

\section{Introduction}

The career of an athlete is influenced by several factors and is characterized by different periods of transition. A key moment is identified by Stambulova (2009) in the transition from junior to senior category. The best junior players are full of big expectations about their future results by coaches, managers and parents. Those expectations are based on talent, ability and/or results in the youth categories. In many cases, those expectations are not based on objective parameters and did not consider that the transition from junior to senior category seems to be one of the biggest obstacles in an athlete's career. As Stambulova (2009) concluded that this transition divided athletes into two equal parts, the larger one stalled and moved on to recreational level sports or terminated their participation and the smaller one continued on to the elite senior level.

Looking at the roll of honor of ETTU, from 1990 onwards only 6 of $47(12.77 \%)$ of the junior champions or runners up in the singles event of European Junior Championship singles have reached the final in the singles event of Senior European Championship through their career. During this process, many players seem to be unable to make this step. A reason for that could be that senior matches are characterized by a different game plan and junior players need to adapt their game.

Table tennis is a highly complex sport which requires observation and analysis to improve knowledge of the performance, the involvement of new knowledge and skills to enhance performance, and an informed coaching process (Hughes et al., 2004). Performance analysis is concerned with tactical and technical evaluation and movement analysis (Carling et al., 2008). In these analyses, researchers are focused on technique analysis, technical effectiveness, as well as tactical and movement analyses. In these analyses, notational/match analysis dominates, which uses means to record aspects of an individual performance (Djokic et al., 2020b).
Notational analysis studies in table tennis are limited. During the last few years, more attention is given to this field, but at the moment, there are still low numbers of publications in particular about tactical indicators. Different authors (Leite et al., 2017; Zagatto et al., 2010; Djokic et al., 2017) analyzed the match characteristics to enhance the comprehension of physical needs and energetic demands of the elite table tennis players with the aim to use better and more precise training workouts.

Some studies were done on rally length. Leite and Zagatto concentrated their studies on the male matches, while Djokic (2017) also analyzed the female matches played at European Games of Baku 2015. Recently, Fuchs and Lames (2015) analyzed the rally length in women matches using different classes.

To the best of our knowledge, there is a very limited number of publications about serve and receive analysis in table tennis. Djokic et al. (2020a; 2020b) analyzed the serve and receive placement of the best European players ranked in top 30 of ETTU ranking list. Malagoli Lanzoni et al. (2014) analyzed the placement of the serve comparing the Asian and European male players and worked on a case study where a player and his opponents are profiled (Malagoli Lanzoni \& Di Michele, 2017) also analyzing the area of serve and receive.

Thus, the aim of this study was to analyze the difference between elite female junior and senior players, using the notational analysis. The notational analysis was used to profile the rally length, serve and receive of two categories of athletes, divided by age, and compare them. In other words, the purpose was to identify possible differences in order to provide useful information to plan specific training sessions. Coaches should be aware of these differences to adopt the optimal coaching strategies for athletes moving from junior to senior female elite competitions. 
Luini, J. D., Fuchs, M., Djokic, Z., Malagoli Lanzoni, I. Munivrana, G. -

Comparasion between European elite senior and junior female table tennis players

2021. Fakultet za sport i turizam, Novi Sad, Tims.Acta 15, 5-12

\section{Methods}

\section{Data Sample}

The sample consisted of 25 women's junior and 25 women's senior single matches, which were played in 2019 and 2020. For the match selection, the following criteria were applied:

- only matches played between offensive players (defensive players and also anti-top or long pimple players are not included as their playing style might not be representative)

- an athlete can be involved in maximum 5 matches to control the impact of a single player on the data

- the players should be in Top 25 of European Senior and Junior Ranking at the date of match

In the end, 50 matches (263 sets, 4958 points) were analyzed.

\section{Performance indicators}

The data about three different fields were collected: rally length, serve analysis and receive analysis.

- $\quad$ Rally length parameter was chosen to analyze the physical effort difference between senior and junior players. The result could influence the training needs of junior players in order to prepare them for the senior category.

- Rally length: is the sum of the strokes hit by the two athletes during a point. In this study, every time one of the athletes touches the ball with the racket one stroke is counted. The point can finish either with an error (that counts for the rally length) or with a winner.

- $\quad$ Serve and receive analyses were selected to report tactical differences that can be eventually noted in the most important strokes of the game, where players try to take advantage and make a tactical decision that gives her edge on her opponent.

- Serve analysis: laterality, technique and placement of serve were analyzed. For the technique's analysis, five categories were selected: pendulum, reverse pendulum, tomahawk, hook and everything else.

Receive analysis: laterality, technique and the placement of receive were analyzed. For technique, based on Molodzoff (2008) the following categories were selected: push, flip (or flick), topspin, drive, smash and everything else.

- Regarding both placement analysis for service and receive, the data were recorded dividing the table in nine fields where position 1, 4, 7 are respectively short / half-long / long in the forehand side; 2, 5, 8 in the middle and 3, 6, 9 in the backhand part.

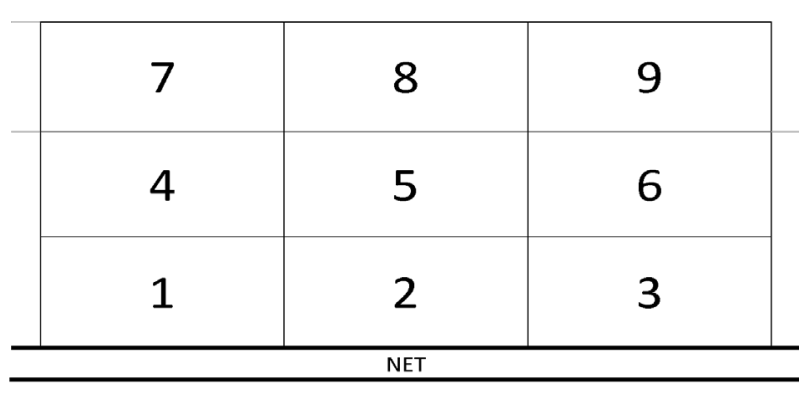

Figure 1. Half table subdivided in 9 areas (Source: Authors)

\section{Data Collection Process}

The footage of the 50 matches selected are available on the official television of European Table Tennis Union (www.laola1.tv), International Table Tennis Federations (tv.ittf.com) and in YouTube ITTF Channel. The matches were seen in slow motion $(0.5 x)$ to collect all the information needed about the matches in a pre-organized excel form. In case of certain inconsistencies, they were rewinded and seen in slow motion $(0.2 \mathrm{X})$. The software used was Kinovea, a free 2D motion analysis software.

\section{Reliability}

For one of the matches, data relative to serves $(n=116)$, receives $(n=116)$ and rally $(n=116)$ were recorded by two different table tennis coaches. Furthermore, the same data were recorded twice within two weeks from the coach who collects all the data of the study. Cohen's Kappa was calculated with the statistical software to assess intra and inter-operator reliability. Based on Landis and Koch (1977), the kappa value can range from -1 to 1 , where 1 indicates perfect agreement.

Intra-operator results show a perfect agreement (1.00) for all the categories and optimal reliability for serve and 
receive placement, respectively 0.83 and 0.87 . Interoperator results show perfect agreement for rally length, service and receive laterality and service technique. The optimal reliability was registered for receive technique (0.97) and good reliability for service and receive placement with Kappa resulting in 0.69 and 0.73 .

\section{Statistical Analysis}

The descriptive statistical data were inserted in a database.

Before conducting tests regarding rally length, the sample was tested for normality as a normal distribution is a prerequisite for many, especially parametric statistical tests (Cohen, 1988). Violations of the assumptions of normality tested with Kolmogorov-Smirnov were found for both age groups. The skewness and kurtosis were also investigated. The results for the juniors (skew $=2.02$, kurt $=6.86$ ) and seniors (skew $=2.49$, kurt $=10.5$ ) confirm moderate non-normal distribution for both groups.

Because of those violations and the resulting impossibility to perform parametric tests on the data, non-parametric Mann-Whitney $U$ test was conducted to analyze if there was a difference in the rally length between the age categories.

All of the statistical analyses were done with a level of significance of $p \leq 0.05$. For service and receive, Pearson's chi-square tests of independence were performed to examine if there was an association between age category and the behavior of players in selected parameters. All the data were analysed using SPSS 20.0 (IBM Corporation, USA).

\section{Results}

\section{Rally Length}

The rally length of 2286 points of junior matches and 2668 of senior matches have been analyzed. The mean rally length is $4.50(S D=2.54)$ in the junior category and 5.37 (SD = 3.47) in the senior category respectively. As shown in the methodology paragraph, means are not representative as the sample is not normally distributed.

For this reason, grouped median were used to compare rally length between the categories, resulting in 3.93 for junior category and 4.46 for senior category.

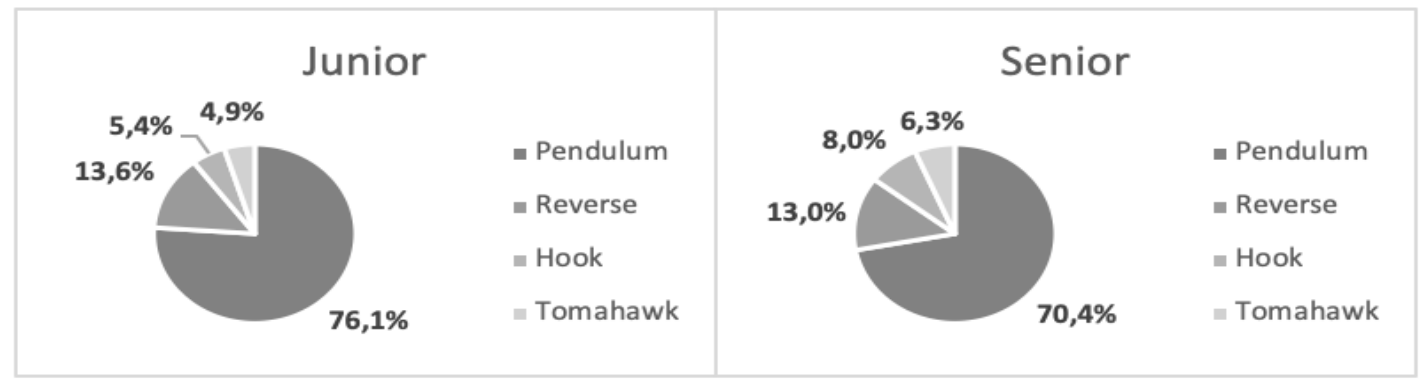

Figure 2. Serve technique's distribution in Junior and Senior Matches (Source: Authors)

\begin{abstract}
A Mann-Whitney test indicated that the difference in rally length between the senior category ( $\mathrm{Mdn}=4.46)$ and the junior category ( $\mathrm{Mdn}=3.93$ ) was statistically significant, $\mathrm{U}\left(\mathrm{N}_{\text {senior }}=2668, \mathrm{~N}_{\text {junior }}=2286\right)=2592280.00, \mathrm{z}=-9.228$, $\mathrm{p}<.001$.
\end{abstract}

\section{Serve Analysis}

The next analysis evaluated the serves for each group. Total of 2282 serves by junior players and 2667 serves by senior players were analyzed.
Regarding laterality, the results show that forehand service is the most used for both junior and senior players $\left(\mathrm{FH}\right.$ service $_{\text {Junior }}=88.6 \%$, FH service Senior $\left.=77.1 \%\right)$. Chisquare test showed a significant association between age groups and laterality of service $(\chi 2(1, N=4949)=$ $113.093, p<.001)$.

The distribution of the different service techniques for both categories highlights the prevalence of the use of Pendulum serve (Junior 76.1 \% vs. Senior $70.4 \%$ ).

Figure 1 shows the distribution of the techniques utilized by the players. In the senior category a greater use of Hook and Tomahawk compared to the junior category 
Luini, J. D., Fuchs, M., Djokic, Z., Malagoli Lanzoni, I. Munivrana, G. -

Comparasion between European elite senior and junior female table tennis players

2021. Fakultet za sport i turizam, Novi Sad, Tims. Acta 15, 5-12

services was registered. Chi-square test revealed a significant association between those two parameters $(\chi 2(3, \mathrm{~N}=4949)=46.805, \mathrm{p}<.001)$ which proves a different service technique behavior between senior and junior players.

The last parameter of serve analysis was the service placement for each group of players. The results (Figure 2) show that short serve in the middle of the table (area 2 ) is the most utilized by both parties (area 2 Junior $=32.3 \%$

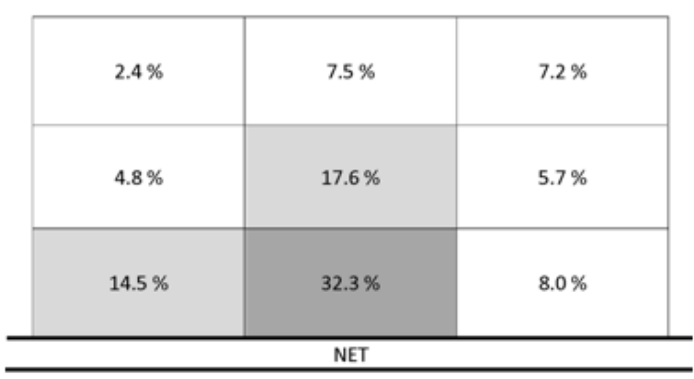

Figure 3. Placement of Serve for Junior Players (Source: Authors)

\section{Receive Analysis}

Receive analysis counts 2233 actions for juniors and 2639 for seniors. Data collected about laterality of the receives shows that junior players have a balanced use of forehand and backhand. In senior matches the forehand receive prevails with $57.5 \%$. Chi-square test revealed a significant association between the parameters ( $\chi 2$ ( 1 , $\mathrm{N}=4872)=24.236, \mathrm{p}>.001$ )

In total, 4872 receive techniques have been analyzed. The results (Table 1) show that the first option of players was the push receive with $54.0 \%$ among seniors and 56.3 $\%$ among juniors. Similar percentages of the offensive techniques (Flip + Tospin $_{\text {Senior }}=43.8 \%$, Flip + Topspin $_{\text {Junior }}$ $=41.2 \%$ ) are shown between categories with different distribution. Flip technique was used more in the senior category (22.2\% vs. $14.7 \%$ ) and topspin in the junior category ( $26.5 \%$ vs $21.6 \%)$.
- area $2_{\text {Senior }}=38.0 \%$ ). Second most used placement for Junior players was the area 5 (17.6\%) followed by area $1(14.5 \%)$. Similar distribution was registered in senior matches (Figure 3), where area $5(18.8 \%$ ) is the second option followed by area 3 and 1 respectively with 11.7 $\%$ and $8.9 \%$. Chi-square results showed a significant association between age groups and the placement of service $(\chi 2(8, N=4884)=135.898, p>.001)$.

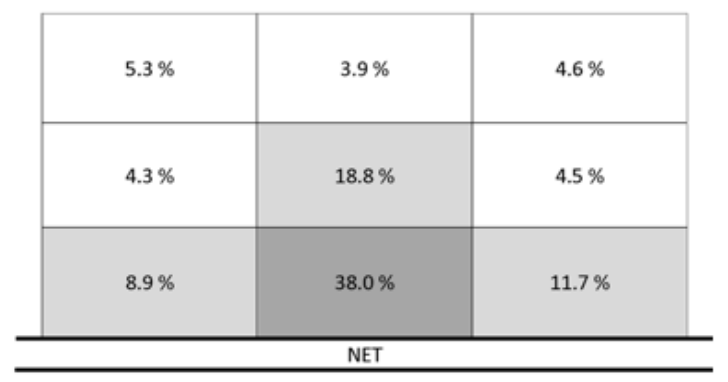

Figure 4. Placement of Serve for Senior Players (Source: Authors)

The Chi-square test result proved that there is a significant association between the age category and receive technique $(\chi 2(5, N=4872)=51.183, p<.001)$.

The combination between laterality and the technique of the receives was additionally analyzed (Table 3 ). The forehand push was the most used method of receiving in both groups $(\mathrm{FH} \mathrm{Push}$ Junior $=34.1 \%, \mathrm{FH} \mathrm{Push}$ Senior $=$ $40.9 \%)$. Juniors used the backhand push (22.2\%) more often compared to the seniors (13.0\%) and also the backhand flip differed with $10.8 \%$ usage by the juniors, and $15.2 \%$ by the seniors. Chi-square test revealed a significant association between the laterality-technique combination and age groups $(\chi 2(10, N=4872)=137.302$ $\mathrm{p}<.001)$.

The last parameter analyzed was the placement of receive. Both age categories indicate area 5 as the most common placement of the receive $(22.8 \%$ for juniors, $22.2 \%$ for

Table 1. Receive technique distribution

\begin{tabular}{|c|c|c|c|c|c|c|c|}
\hline & Push & Filip & Topspin & Drive & Smash & EE & Total \\
\hline \multirow{2}{*}{ Junior } & 1257 & 329 & 593 & 6 & 1 & 47 & 2233 \\
\hline & $56.3 \%$ & $14.7 \%$ & $26.5 \%$ & $0.3 \%$ & $0.1 \%$ & $2.1 \%$ & $100 \%$ \\
\hline \multirow{2}{*}{ Senior } & 1424 & 588 & 569 & 9 & 1 & 48 & 2639 \\
\hline & $54.0 \%$ & $22.2 \%$ & $21.6 \%$ & $0.3 \%$ & $0.1 \%$ & $1.8 \%$ & $100 \%$ \\
\hline
\end{tabular}

(Source: Authors) 
Luini, J. D., Fuchs, M., Djokic, Z., Malagoli Lanzoni, I. Munivrana, G. -

Comparasion between European elite senior and junior female table tennis players

2021. Fakultet za sport i turizam, Novi Sad, Tims.Acta 15, 5-12

seniors). The short receive distribution is concentrated in area 2 in both categories (11.5\% Junior $-13.6 \%$ Senior). Differences were registered in the long receives. Juniors prefer to play in the middle and backhand zones (area 8 $=19.0 \%$ and area $9=20.7 \%$ ), differently for senior that have a greater frequency in the middle of the table (area 8 $=19.7 \%$ ) and balanced distribution between outer zones (area $7=14.0 \%$ and area $9=13.7 \%$ ).
The chi-square test result has shown a significant association between age groups and the placement of the receive $(\chi 2(8, N=4312)=63.714, p<.001)$.

Table 2. Distribution of receive technique divided for laterality

\begin{tabular}{|c|c|c|c|c|c|c|c|c|c|c|c|c|c|}
\hline & \multicolumn{2}{|c|}{ Push } & \multicolumn{2}{|c|}{ Flip } & \multicolumn{2}{|c|}{ Topspin } & \multicolumn{2}{|c|}{ Smash } & \multicolumn{2}{|c|}{ Drive } & \multicolumn{2}{|c|}{$\mathrm{EE}$} & \multirow[t]{2}{*}{ Total } \\
\hline & FH & $\mathrm{BH}$ & FH & $\mathrm{BH}$ & FH & $\mathrm{BH}$ & FH & $\mathrm{BH}$ & FH & $\mathrm{BH}$ & FH & $\mathrm{BH}$ & \\
\hline \multirow{2}{*}{ Junior } & 762 & 495 & 85 & 244 & 263 & 330 & 5 & 1 & 1 & 0 & 11 & 36 & 2233 \\
\hline & $34.1 \%$ & $22.2 \%$ & $3.8 \%$ & $10.8 \%$ & $11.8 \%$ & $14.7 \%$ & $0.2 \%$ & $0.1 \%$ & $0.1 \%$ & $0.0 \%$ & $0.5 \%$ & $1.6 \%$ & $100 \%$ \\
\hline \multirow{2}{*}{ Senior } & 1080 & 344 & 183 & 405 & 242 & 327 & 0 & 9 & 1 & 0 & 12 & 36 & 2639 \\
\hline & $40.9 \%$ & $13.0 \%$ & $6.9 \%$ & $15.2 \%$ & $9.2 \%$ & $12.4 \%$ & $0.0 \%$ & $0.3 \%$ & $0.1 \%$ & $0.1 \%$ & $0.5 \%$ & $1.6 \%$ & $100 \%$ \\
\hline
\end{tabular}

(Source: Authors)

\section{Discussion}

The purpose of this paper was to compare rally length and serve/receive behavior between senior and junior women's matches. The result of the average rally length of senior matches (4.46) was lower than both results of the $6.3 \pm 2.8$ of Djokic et al. (2017) and 5.11 (SD = 4.46) of Fuchs and Lames (2015). The reason for the differences

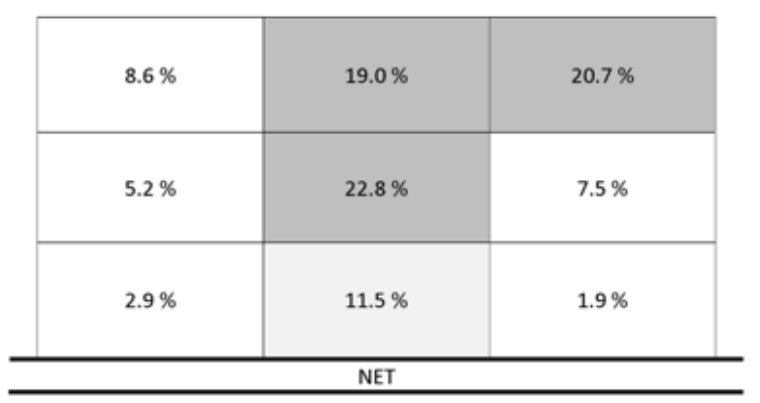

Figure 5. Placement of receive for junior players (Source: Authors)

players need to focus their training on the development of strokes' consistency and physical capacities, in order to enhance the number of strokes on the table. Regarding this theory, the ideal situational training for the junior players should include exercises with a high number of strokes. Following the proposal of Djokic et al. (2017), at least 7 strokes.

Receive analysis has shown a different distribution in the offensive strokes. The topspin technique in receiving depends on the placement of serve and in particular is caused by a long serve of the opponent. Flip technique between the results of (this) these studies could be that each study has used different methods to calculate the average rally length.

Senior players have a higher number of strokes per rally: the reasons for that might be that senior players have more consistency of strokes and higher physical capacity to perform them. The consequence could be that junior

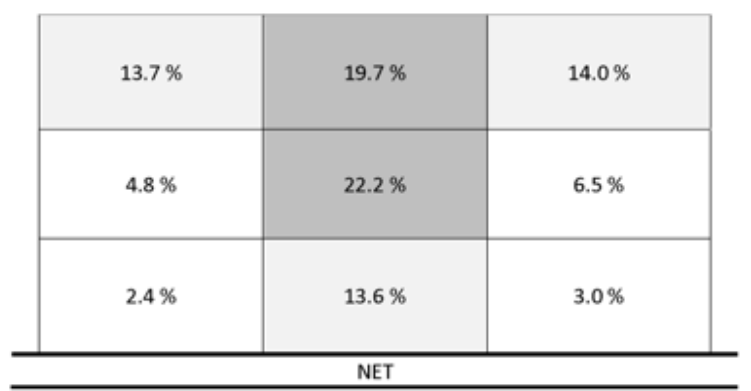

Figure 6. Placement of receive for senior players (Source: Authors)

is a choice of the player to return a short service. A reason for the greater use of backhand flip technique of senior players compared to the juniors, could be that first topspin on push played by senior players is likely more consistent and more dangerous compared to the junior category. In particular, in case of a low-quality push of the opponent, senior players can hit a winner with the high percentage of realization. Senior players seem to be on a higher technical level, which offered better chances to the receiver to win points when the opponent had to serve. With this view, using the flip technique could be 
a tactical solution that can avoid advantage for serve in the senior category, differently from the junior category where players could take advantage of less power and consistency of the opponent's first topspin after an intentionally long push.

Further analysis of receive was done with specific attention to the placement of the push receive. Results show a difference in short placement (32,5\% for seniors vs $26,0 \%$ for juniors). Like in elite senior table tennis (Djokic et al., 2020a), the short serve prevailed in their serve tactic. In order to minimize the use of the first topspin of the opponent, senior players used short receives more often, while junior players used more long push exploiting the less efficient topspin of the opponent. In men elite seniors (Djokic et al., 2020b), the most frequently used stroke of serving returns was short placed forehand backspin stroke, which is characterized as neutral stroke enabling the continuation of the rally (Malagoli Lanzoni et al., 2014). These results show a difference between the tactical game plan of junior and senior category regarding receive. In particular, it seems that senior players would limit the first topspin on push of the opponent using short receive or in alternative use flip to take initiative earlier. Instead, junior players prefer to push long in order to take advantage of minor consistency of junior's topspin that can result in higher number of direct errors and because of the low effectiveness that permit a counterattack or an active block with a good percentage of success.

In particular, for the receive behavior during the developmental process, the coach should encourage players to train and use different solutions in order to avoid the long push. Also, sometimes it is not the best tactic solution in relation to the opponent. Young players could be encouraged to limit the long push receive. Also, it seems that in their category could be the best tactic solution. The return to a serve is one the most important shots in table tennis (Muster, 1999).

Some potential limitations of this study need to be mentioned. With 25 matches per age category, the selected sample is relatively small. Thus, although respecting the selected criteria in match selection, a single player who might be participating in 5/25 matches might have a bigger influence on the results than other players and could skew the statistics, especially if that certain player is often performing rare serving/receives. Another potential limitation could be the identification of the correct placement of the ball with the 9-area system, that shows a good inter and intra-operator reliability, but multiply the evaluation of the operator on the certain consistencies.

\section{Conclusion}

The results of the study demonstrated that significant differences are present between the junior and senior female category.

The consistency of strokes and higher physical capacity seems to be fundamental to enhance their performance. Moreover, the biggest difference was registered in the receiving game. This might be a consequence of a possible different general game plan of senior players and might be important parameters when evaluating junior players if they are ready to face the senior category. Considering that the transition from junior to senior category is influenced by a high number of factors, coaches should be aware of the future technical, tactical and physical demands that the senior level requires. Junior players (especially in last years in junior category) should be addressed in training to focus on the aspects where their game plan differs from senior behavior.

Certainly, more research is needed to confirm the assumptions formulated on the results of this paper and in particular to assess the role of serve and receive capacity in predicting future success of junior players. Moreover, future research could also involve the Asian players, where junior players will be supposed to become the future Top 10 players of the World.

\section{STATEMENT}

In their statements, the authors confirmed the absence of any conflict of interest.

\section{REFERENCES}

Carling, C., Reilly, T., \& Williams, A. M. (2008). Performance Assessment for Field Sports. London, UK: Routledge.

Cohen, J. (1988). Statistical power analysis for the behavioral sciences. Hillsdale: Lawrence Erlbaum.

Djokic, Z., Malagoli Lanzoni, I. Katsikadelis, M., \& Straub, G. (2020a). Serve Analyses in elite European table tennis matches. International Journal of Racket Sport Science, 2(1), 1-8.

Djokic Z., Malagoli Lanzoni, I., Katsikadelis, M., \& Straub, G. (2020b). Receive analyses in elite European table tennis matches. In Kondrič. M., Paar, D. \& Kamijima, K. Proceedings book of the $16^{\text {th }}$ Sports Science Congress. Lausanne: International Table Tennis Federation (163-171), Hungarian Table Tennis Association, University of Pécs. 
Luini, J. D., Fuchs, M., Djokic, Z., Malagoli Lanzoni, I. Munivrana, G. -

Comparasion between European elite senior and junior female table tennis players

2021. Fakultet za sport i turizam, Novi Sad, Tims.Acta 15, 5-12

Djokic, Z., Munivrana, G., \& Levajac, D. (2017). Match characteristics of professional European male table tennis players. $15^{\text {th }}$ ITTF Sport Science Congress.

Fuchs, M., \& Lames, M. (2015). Rally Length in Top Level Table Tennis. $14^{\text {th }}$ ITTF Sport Science Congress.

Hughes, M., Cooper, S. M., \& Nevill, A. (2004). Analysis of notation data: reliability. In Hughes, M. \& Franks, M. I. (Eds.) Notational Analysis of Sport-Systems for better coaching and performance in sport (pp. 189-204). Second Edition, London: Routledge

Landis R. J., \& Koch, G. G. (1977). The measurement of observer agreement for categorical data. Biometrics, Vol. 33, No. 1, 159-174.

Leite, J. V. M., Barbieri, F. A., Miyagi, W. E., Malta, E. S., \& Zagatto, A. M. (2017). Influence of game evolution and the phase of competition on temporal game structure in high-level table tennis tournaments. Journal of Human Kinetics, 55, 55-57.

Malagoli Lanzoni I., Di Michele R., \& Merni, F. (2014). A notational analysis of shot characteristics in top-level table tennis players, European Journal of Sport Science, 14(4), 309-317, DOI:10.108 0/17461391.2013.819382

Malagoli Lanzoni, I., \& Di Michele, R. (2017). Notational analysis in top-level table tennis: a case study. Book of abstract " $15^{\text {th }}$ ITTF Sport Science Congress. p. 42.

Molodzoff, P. (2008). Advanced coaching manual. Lausanne: International Table Tennis Federation.

Muster, M. (1999). Zur Bedeutung des "situativen Trainings" im Hochleistungstischtennis - empirische Untersuchung zur Identifikation von "Spielsituationen" (The significance of "situational training" in high-performance table tennis - an empirical study for the identification of "game-play situations"). Unpublished doctoral dissertation. Technical University of Munich, Munch, Germany. In German.

Stambulova, N. (2009). Talent development in sport: A career transition perspective. In Tsung-Min Hung, E., Lidor, R. and Hackfort, D. (Eds.) Psychology of sport excellence (pp. 63-74). Morgantown, WV: Fitness Information Technology.

Zagatto, A. M., Morel, E. A., \& Gobatto, C. A. (2010). Physiological responses and characteristics of table tennis matches determined in official tournaments. Journal of Strength and Condition Research, 24(4), 942-949.

Datum prijave: 03. 06. 2021.

Datum prihvatanja: 23. 06. 2021.

\section{Kontakt}

Jason Davide Luini, University of Split,

Faculty of Kinesiology, Split, Croatia

Email: jason.luini@gmail.com

Michael Fuchs, TUM Department of Sport and Health

Sciences, Munich, Germany

Email: michael.fuchs@mytum.de
Zoran Djokic, Faculty of Sport and Tourism,

Novi Sad, Serbia

Email: zoran.djokic@tims.edu.rs

Ivan Malagoli Lanzoni, University of Bologna,

Department of Biomedical and Neuromotor Sciences,

Bologna, Italy

Email: ivan.malagoli@unibo.it

Goran Munivrana, University of Split, Faculty of Kinesiology, Split, Croatia

Email: goran.munivrana@kifst.hr 